\title{
Shewanella frigidimarina and Shewanella livingstonensis sp. nov. isolated from Antarctic coastal areas
}

Laboratori de Microbiologia, Facultat de Farmacia, Universitat de Barcelona, Av. Joan XIII s/n, 08028

Barcelona, Spain

\author{
Núria Bozal, M. Jesús Montes, Encarna Tudela, Francisco Jiménez \\ and Jesús Guinea
} Author for correspondence: Jesús Guinea. Tel: +34 934024497 . Fax: + 34934024498.
e-mail: jguinea@farmacia.far.ub.es
Keywords: Antarctica, Shewanella frigidimarina, Shewanella livingstonensis, polyphasic taxonomy

\section{INTRODUCTION}

The genus Shewanella was first described 14 years ago by MacDonell \& Colwell (1985). The definition of Shewanella was based almost entirely on rRNA structure and included only the description 'straight or curved rods, Gram-negative, non-pigmented, motile by polar flagella, chemo-organotrophic, oxidasepositive, generally associated with aquatic or marine habitats. G $+\mathrm{C}$ mol \% 44-47'. The species Shewanella putrefaciens (Derby \& Hammer, 1931; Lee et al., 1977) and Shewanella hanedai (Jensen et al., 1980) were included in the new genus, as well as the new description of Shewanella benthica. Twelve species are

Abbreviation: TMAO, trimethylamine $N$-oxide.

The EMBL accession numbers for the 16S rDNA gene sequence of strains NF12 and NF22 ${ }^{\top}$ are AJ300833 and AJ300834, respectively. included in the genus Shewanella, nine of which have been described in the last 3 years. Although the development of this bacterial group, from a taxonomic point of view, has taken place in the last decade, Shewanella putrefaciens has been studied since its first description as Achromobacter putrefaciens by Derby \& Hammer (1931), because of its special interest in the areas of applied and environmental microbiology.

Shewanella putrefaciens, first isolated as Achromobacter putrefaciens from rancid butter, was classified in 1960 as Pseudomonas putrefaciens by Shewan et al. (1960) and, later, as Alteromonas putrefaciens by Lee et al. (1977). This micro-organism has been found to be associated with the spoilage of proteinaceous foods (Shewan, 1977). Shewanella species are widely distributed and have been isolated from diverse sources such as aquatic environments (Nealson et al., 1991), sediments (Myers \& Nealson, 1988), oilfield fluids 
(Semple \& Westlake, 1987) and, as mentioned above, spoilage of proteinaceous foods (Levin, 1972; Shewan, 1974; Parker \& Levin, 1983; Stenstrom \& Molin, 1990), and are considered opportunistic pathogens of humans (Debois et al., 1975; Nozue et al., 1992; Brink et al., 1995) and aquatic animals (Aguirre et al., 1994). This has been pointed out by many authors since the description of some Pseudomonas-like marine bacteria by Lee et al. (1977) through to the more recent description of Shewanella pealeana by Leonardo et al. (1999).

Venkateswaran et al. (1999) described the phylogenetic relationship between the described species of Shewanella, including Shewanella putrefaciens, Shewanella hanedai, Shewanella benthica, Shewanella colwelliana (Weiner et al., 1988; Coyne et al., 1989), Shewanella algae (Simidu et al., 1990; Nozue et al., 1992; Trüper \& de'Clari, 1997), Shewanella woodyi (Makemson et al., 1997), Shewanella gelidimarina and Shewanella frigidimarina (Bowman et al., 1997), Shewanella baltica (Ziemke et al., 1998) Shewanella amazonensis (Venkateswaran et al., 1998), Shewanella oneidensis (Venkateswaran et al., 1999) and Shewanella pealeana (Leonardo et al., 1999).

Here we describe the isolation of three strains of the genus Shewanella, capable of growing anaerobically by dissimilatory $\mathrm{Fe}$ (III) reduction, from muddy soil, water and sediments collected in the Antarctic area of the South Shetland Islands. To elucidate the taxonomic position of these three isolates, conventional phenotypic and chemotaxonomic analyses were performed. The results obtained and the DNA-DNA hybridization and 16S RNA sequence analysis suggested that the organisms should be included in the genus Shewanella.

\section{METHODS}

Bacterial strains and isolation. The bacterial strains used in this study are listed in Table 1. Strain NF12 was isolated from mud collected in the Inlet Admiralty Bay (King George Island, South Shetland Islands, Antarctica), at the bottom of a glacier which is covered at high water. Strains NF22 ${ }^{\mathrm{T}}$ and NF24 were isolated from sediment and water, respectively, collected in Johnson's Dock (Livingston Island, South Shetland Islands, Antarctica).

Aliquots of samples were removed with a platinum loop and diluted in a saline solution containing $\left(\mathrm{g} \mathrm{l}^{-1}, \mathrm{pH} \mathrm{7)}\right.$ : $\mathrm{NaCl}$, $0 \cdot 56 ; \mathrm{KCl}, 0 \cdot 27 ; \mathrm{CaCl}_{2}, 0.03 ; \mathrm{NaHCO}_{3}, 0 \cdot 01$. Trypticase soy agar (TSA; ADSA) plates were inoculated with loopfuls of several sample dilutions using the streak plate method to obtain well isolated colonies. Petri dishes were incubated for $6 \mathrm{~d}$ at $15^{\circ} \mathrm{C}$. Isolates were maintained on TSA slopes at $4{ }^{\circ} \mathrm{C}$. Bacteria were also stored at $-20{ }^{\circ} \mathrm{C}$ in $50 \%$ (v/v) glycerol. All media used in this study were sterilized at $121^{\circ} \mathrm{C}$ for $20 \mathrm{~min}$, unless otherwise indicated.

Morphology. Cell size and morphology were determined by scanning electron microscopy of cells grown in Trypticase soy broth (TSB; ADSA) at $15^{\circ} \mathrm{C}$. A Hitachi model S 3200 scanning electron microscope was used. Motility was determined by phase-contrast microscopy. The flagellar arrangement was examined with a Philips model 301 microscope and negative staining with $0.5 \%$ (w/v) phosphotungstic acid adjusted to $\mathrm{pH} 6$ with $1 \mathrm{M} \mathrm{KOH}$ was applied. TSB cultures, grown for $24 \mathrm{~h}$, were used.

Physiological and biochemical characteristics. Oxidase activity was tested using the method of Kovács (1956). Catalase activity, nitrate reduction, ornithine, arginine and lysine decarboxylase activity were determined following Cowan \& Steel (1993). The arginine dihydrolase reaction test was performed according to Thornley (1960), as modified by Lelliot et al. (1966). Acid production from carbohydrates was tested on the oxidation-fermentation medium of Leifson (1963) after incubation at $15^{\circ} \mathrm{C}$ for $14 \mathrm{~d}$.

Degradative tests were carried out at $15^{\circ} \mathrm{C}$. Tween $80(1 \%$, $\mathrm{v} / \mathrm{v})$ was incorporated into Sierra's medium (Sierra, 1957) and plates were examined for opacity after $5 \mathrm{~d}$. Hydrolysis of DNA was tested by the method of Jeffries et al. (1957). Hydrolysis of starch, aesculin, gelatin, casein, lecithin and chitin were determined following Cowan \& Steel (1993). Haemolytic activity was tested on blood agar plates according to Cowan \& Steel (1993).

API galleries (API 20E, API 20EN, ATB 32GN, API 20B, API ZYM; bioMérieux) were used to test additional biochemical characteristics and were prepared according to the manufacturer's instructions. The API strips were incubated for $5 \mathrm{~d}$ at $15^{\circ} \mathrm{C}$.

The $\mathrm{pH}$ range for the growth of each strain was determined in TSB with $\mathrm{pH}$ values of separate batches of medium adjusted to $4,5,6,7,8,9$ and 9.5 with $1 \mathrm{M} \mathrm{HCl}$ and $1 \mathrm{M}$ $\mathrm{NaOH}$. The test media were incubated at $15^{\circ} \mathrm{C}$ for $14 \mathrm{~d}$. The temperature range for growth was determined on TSA and TSA containing $3 \%(\mathrm{w} / \mathrm{v}) \mathrm{NaCl}$, incubated for $14 \mathrm{~d}$ at 4,11 , $16,20,25,30,37$ and $40^{\circ} \mathrm{C}$. Salt tolerance tests were performed on TSA with $\mathrm{NaCl}$ concentrations ranging from $0 \cdot 6$ to $20 \%(\mathrm{w} / \mathrm{v})$.

The sodium requirement was analysed in a medium containing $\left(\mathrm{g} \mathrm{l}^{-1}, \mathrm{pH} 7\right): \mathrm{K}_{2} \mathrm{HPO}_{4}, 5 \cdot 0 ; \mathrm{MgSO}_{4} \cdot 7 \mathrm{H}_{2} \mathrm{O}, 0 \cdot 5$; $\mathrm{CaCl}_{2}, 0.05 ; \mathrm{FeSO}_{4} .7 \mathrm{H}_{2} \mathrm{O}, 0.028 ; \mathrm{NH}_{4} \mathrm{Cl}, 7$; yeast extract, $5 \cdot 0$; agar, 20.0. Another medium with the same composition, except that it contained $1 \mathrm{~g} \mathrm{NaCl}^{-1}$, was used as a positive control. A solution with all of the ingredients except $\mathrm{CaCl}_{2}$ and $\mathrm{FeSO}_{4}$ was sterilized by autoclaving it at $0.5 \mathrm{~atm}$ $\left(5.065 \times 10^{4} \mathrm{~Pa}\right)$ for $30 \mathrm{~min}$. $\mathrm{CaCl}_{2}$ and $\mathrm{FeSO}_{4}$ were added aseptically from sterile stock solutions. Plates were incubated for $14 \mathrm{~d}$ at $15^{\circ} \mathrm{C}$.

Carbon source utilization tests were performed in a mineral medium containing ( $\left.\mathrm{g} \mathrm{l}^{-1}, \mathrm{pH} 7\right): \mathrm{Na}_{2} \mathrm{HPO}_{4}, 10 \cdot 0 ; \mathrm{KH}_{2} \mathrm{PO}_{4}$, $3 \cdot 0 ; \mathrm{K}_{2} \mathrm{SO}_{4}, 1 \cdot 0 ; \mathrm{NaCl}, 1 \cdot 0 ; \mathrm{MgSO}_{4} \cdot 7 \mathrm{H}_{2} \mathrm{O}, 0 \cdot 4 ; \mathrm{CaCl}_{2}, 0 \cdot 1$; $\mathrm{FeSO}_{4} \cdot 7 \mathrm{H}_{2} \mathrm{O}, 0 \cdot 018, \mathrm{NH}_{4} \mathrm{Cl}, 3 \cdot 0$. The carbon source concentration used was $1 \%$, as described by Palleroni \& Doudoroff (1972).

Dissimilatory iron reduction was tested on a defined medium (Myers \& Nealson, 1988, 1990) supplemented with $30 \mathrm{mM}$ lactate as carbon and energy source and $50 \mathrm{mM} \mathrm{Fe(III)}$ citrate as terminal electron acceptor (Lovley et al., 1992). Solid defined medium (DiChristina \& DeLong, 1994) was prepared by adding Bacto Agar (Difco) to a final concentration of $1.5 \%(\mathrm{w} / \mathrm{v})$. Anaerobic growth, with $25 \mathrm{mM}$ trimethylamine $N$-oxide (TMAO) (Saffarini et al., 1994) as sole terminal electron acceptor, was tested on the same solid defined medium in which $\mathrm{Fe}$ (III) citrate was omitted. The 
Table 1. Strains used in this study

ACAM, Australian Collection of Antarctic Micro-organisms, University of Tasmania, Tasmania, Australia; ATCC, American Type Culture Collection, Manassas, VA, USA; CECT, Spanish Type Culture Collection (Colección Española de Cultivos Tipo), Burjasot, Valencia, Spain; LMG, BCCM/LMG Bacteria Collection, Laboratorium voor Microbiologie, University of Ghent, Ghent, Belgium; NCTC, National Collection of Type Cultures, Public Health Laboratory, London, UK.

\begin{tabular}{|c|c|c|}
\hline Strain & Other designations & Source \\
\hline Shewanella putrefaciens $\mathrm{LMG} 2268^{\mathrm{T}}$ & ATCC $8071^{\mathrm{T}}$ & LMG \\
\hline Shewanella putrefaciens LMG 2369 & & LMG \\
\hline Shewanella algae CECT 331 & & CECT \\
\hline Shewanella algae LMG 2265 & & LMG \\
\hline Shewanella baltica CECT $323^{\mathrm{T}}$ & LMG $2250^{\mathrm{T}}, \mathrm{NCTC} 10735^{\mathrm{T}}$ & CECT, LMG \\
\hline Shewanella frigidimarina $\mathrm{LMG} 19475^{\mathrm{T}}$ & ACAM $591^{\mathrm{T}}$ & LMG \\
\hline Shewanella hanedai CECT $5017^{\mathrm{T}}$ & ATCC $33224^{\mathrm{T}}$ & CECT \\
\hline NF12 & LMG 19867, CECT 5932 & Glacier mud, Admiralty Bay, Antarctica \\
\hline $\mathrm{NF} 22^{\mathrm{T}}$ & LMG $19866^{\mathrm{T}}$, CECT $5933^{\mathrm{T}}$ & Water, Johnson's Dock, Antarctica \\
\hline NF24 & LMG 19868, CECT 5934 & Sediment, Johnson's Dock, Antarctica \\
\hline
\end{tabular}

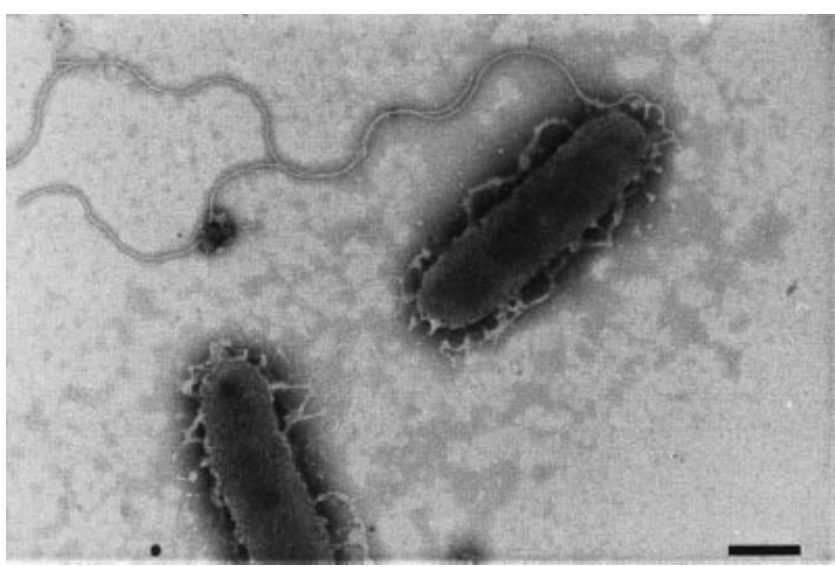

Fig. 1. Electron micrograph of negatively stained cells of NF24 from a liquid culture after $24 \mathrm{~h}$ incubation at $15^{\circ} \mathrm{C}$. Bar, $0.55 \mu \mathrm{m}$.

inoculated plates [defined medium $\mathrm{Fe}(\mathrm{III})$ citrate or defined medium TMAO] were incubated under anaerobic conditions (Gas Pack system) for 10-14 d until the plates showed visible growth. Incubations were carried out in the dark at $15^{\circ} \mathrm{C}$ for bacterial isolates and at room temperature $\left(22^{\circ} \mathrm{C}\right)$ for Shewanella algae CECT 331 and Shewanella baltica CECT $323^{\mathrm{T}}$. Before storage at 15 and $22^{\circ} \mathrm{C}$, each anaerobic jar was kept overnight at $4{ }^{\circ} \mathrm{C}$ to make sure that anoxic conditions had developed before allowing strain growth. Growth on the plates was compared with growth on two sets of defined medium control plates, one lacking electron acceptors and the other lacking organic carbon substrate.

Antibiotic sensitivities. Susceptibility to antibiotics was tested by using the method of Bauer et al. (1966). Disks (6.5 mm diam.) impregnated with antibiotics (bioMérieux) were laid on Müeller-Hinton agar (ADSA) plates which had been surface-inoculated with test strains.

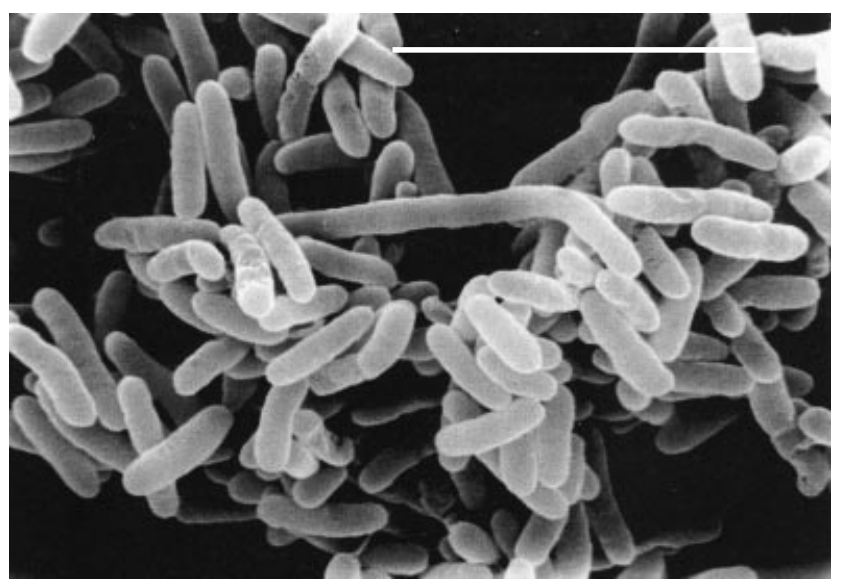

Fig. 2. Morphology of strain $N F 22^{\top}$ by scanning electron microscopy. Cells were grown on TSB for $24 \mathrm{~h}$ at $15^{\circ} \mathrm{C}$. Bar, $5 \mu \mathrm{m}$.

Fatty acid composition. Fatty acids were prepared from $40 \mathrm{mg}$ wet cell material harvested from a TSB agar $(30 \mathrm{~g}$ TSB, $15 \mathrm{~g}$ agar; BBL) culture incubated for $5 \mathrm{~d}$. Bacterial isolates were grown at 8 and $15^{\circ} \mathrm{C}$ and Shewanella algae CECT 331 at room temperature $\left(22^{\circ} \mathrm{C}\right)$. Whole-cell fatty acids were isolated following the Microbial Identification System (MIS) guidelines (Microbial ID) and were analysed by GLC with a Hewlett Packard model HP5890A instrument. Fatty acids were identified and quantified by comparison with other micro-organisms, using MIDI System software, version 3.2. The relative amount of each fatty acid in a strain was expressed as a percentage of total fatty acids.

Quinone analysis. Strains NF12, NF22 ${ }^{\mathrm{T}}$ and NF24 were grown in $250 \mathrm{ml}$ TSB medium and Shewanella species in $250 \mathrm{ml}$ TSB medium with seawater. Cultures were incubated by shaking at 150 r.p.m. for $24 \mathrm{~h}$ at $15^{\circ} \mathrm{C}$ for bacterial isolates and at room temperature $\left(22^{\circ} \mathrm{C}\right)$ for the reference strains. Biomass was harvested and lyophilized. 
Table 2. Biochemical and physiological characteristics of strains NF12, NF22 ${ }^{\top}$ and NF24 isolated from Antarctic environments

All strains studied were straight polarly flagellated rods that were positive for catalase, oxidase and nitrate reduction, had no sodium requirement for growth and had negative Voges-Proskauer and indole reactions. The range of $\mathrm{pH}$ tolerance for growth was 6-9.5 for the three strains. They hydrolysed aesculin and Tween, but none hydrolysed starch. All of the strains were positive in tests for alkaline and acid phosphatase, esterase (C4), esterase lipase (C8), leucine arylamidase, cystine arylamidase, naphtholAS-BI-phosphohydrolase and $\alpha$-glucosidase, but negative in tests for urease, DNase, lecithinase, $\alpha$-galactosidase, trypsin, $\beta$ glucuronidase, $\beta$-glucosidase, $N$-acetyl- $\beta$-glucosaminidase, $\alpha$-fucosidase, arginine dihydrolase, ornithine decarboxylase, arginine decarboxylase and lysine decarboxylase. The following carbon and energy sources were not used by any strain: L-arabinose, D-arabinose, gluconate, caprate, adipate, citrate, phenylacetate, salicin, D-melibiose, L-fucose, D-sorbitol, valerate, histidine, 2-ketogluconate, 4-hydroxybenzoate, $\alpha$-L-rhamnose, itaconate, suberate, acetate, propionate, 5-ketogluconate, glycogen, 3-hydroxybenzoate, DL-malate, pimelate, D-fructose, sebacate, $m$-tartrate, DL-hydroxybutyrate and L-phenylalanine. All strains used D-glucose, maltose, cellobiose, sucrose, D-mannose, D-mannitol, D-galactose, D-xylose, $N$-acetylglucosamine, trehalose, malonate and succinate. All strains were capable of fermenting D-glucose, maltose, cellobiose, sucrose, D-mannose, D-mannitol, D-galactose, D-xylose, $N$-acetylglucosamine and trehalose. All strains were able to oxidatively produce acid from D-glucose, maltose and cellobiose, but not from L-arabinose, fructose, rhamnose, galactose, sorbitol, glycerol, $N$-acetylglucosamine or trehalose. All strains were susceptible to penicillin, $10 \mathrm{U}$ per disk; tobramycin, $10 \mu \mathrm{g}$ per disk; nalidixic acid, $30 \mu \mathrm{g}$ per disk; chloramphenicol, $30 \mu \mathrm{g}$ per disk; and tetracycline, $30 \mu \mathrm{g}$ per disk. + , Positive; - , negative.

\begin{tabular}{|c|c|c|c|}
\hline Characteristic & NF12 & $\mathrm{NF}^{\mathrm{T}}{ }^{\mathrm{T}}$ & NF24 \\
\hline Cell length $(\mu \mathrm{m})$ & $1-2 \cdot 5$ & $1-3$ & $1-3 \cdot 7$ \\
\hline Cell diameter $(\mu \mathrm{m})$ & $0 \cdot 3-0 \cdot 5$ & $0 \cdot 4$ & $0 \cdot 5$ \\
\hline Temperature range of growth $\left({ }^{\circ} \mathrm{C}\right)$ & $4-30$ & $4-20$ & $4-20$ \\
\hline Maximum $\mathrm{NaCl}$ concentration tolerated $(\%, \mathrm{w} / \mathrm{v})$ & $5 \cdot 5$ & 5 & 9 \\
\hline $\mathrm{H}_{2} \mathrm{~S}$ production (Kligler, $\mathrm{TSI}$ ) & - & + & - \\
\hline $\mathrm{G}+\mathrm{C}$ content $(\mathrm{mol} \%)$ & 42 & 41 & 42 \\
\hline \multicolumn{4}{|l|}{ Hydrolysis of: } \\
\hline Gelatin, casein & + & + & - \\
\hline Chitin & + & - & + \\
\hline \multicolumn{4}{|l|}{ Enzyme activity } \\
\hline Lipase (C4), $\alpha$-chymotrypsin & + & - & + \\
\hline$\beta$-Galactosidase (ONPG) & - & + & - \\
\hline$\alpha$-Mannosidase & - & - & + \\
\hline \multicolumn{4}{|l|}{ Oxidative acid production from: } \\
\hline Sucrose, D-mannose & - & - & + \\
\hline Starch & + & - & - \\
\hline D-Mannitol & + & - & + \\
\hline D-Galactose, D-xylose & - & + & - \\
\hline \multicolumn{4}{|l|}{ Utilization of: } \\
\hline L-Glutamate & + & - & + \\
\hline 3-Hydroxybutyrate, L-proline, inositol, sucrose, L-alanine, L-serine & - & - & + \\
\hline D-Ribose, DL-lactate & - & + & + \\
\hline
\end{tabular}

Isoprenoid quinones were extracted from lyophilized ground cells by the method of Minnikin et al. (1984). HPLC was carried out to determine the isoprenoid quinone composition according to Tamaoka et al. (1983). The apparatus comprised a high-performance liquid chromatograph Phoenix 20 (Punts CE Instruments), a Kontron 535 UV detector (Kontron Instruments) and a reverse-phase type Spherisorb ODS2 $(5 \mu \mathrm{m})$ column $(4.6 \mathrm{~mm}$ i.d. $\times 150 \mathrm{~mm}$; Waters $)$. Samples were eluted with a mixture of acetonitrile/2propanol $(65: 35, \mathrm{v} / \mathrm{v})$ at a flow rate of $1 \mathrm{ml} \mathrm{min}^{-1}$. Quinones were identified by MS (Platform Micromass) using a flow divisor $1 / 50$ to apply the appropriate flow. The conditions for chemical ionization at atmospheric pressure (APCI) were: discharge needle, $3000 \mathrm{~V}$; counter-electrode, $500 \mathrm{~V}$; sampling cone, $40 \mathrm{~V}$; photomultiplicator, $650 \mathrm{~V}$; source temperature, $80^{\circ} \mathrm{C}$; tip temperature, $400^{\circ} \mathrm{C}$. The relative molar ratios of quinone homologues were determined by reference to the standard mixtures containing known amounts of MK-4 and Q-10.

Whole-cell protein profiles. To obtain whole-cell protein extracts, the Antarctic isolates and Shewanella species were grown on TSA plates for $5 \mathrm{~d}$ at $15^{\circ} \mathrm{C}$ and at room temperature $\left(22^{\circ} \mathrm{C}\right)$, respectively. The bacterial growth on three Petri dishes was harvested and resuspended in $7 \mathrm{ml}$ NaPBS buffer ( $0 \cdot 2 \mathrm{M}$ sodium phosphate buffer, $\mathrm{pH} 7 \cdot 3,8 \mathrm{~g}$ $\left.\mathrm{NaCl}^{-1}\right)$. The bacterial suspension was filtered through nylon gauze and centrifuged for $20 \mathrm{~min}$ at $5000 \mathrm{~g}$. The pellet was washed twice in the same buffer and $70 \mathrm{mg}$ (wet wt) bacterial cells was transferred into an Eppendorf centrifuge tube. A $0.9 \mathrm{ml}$ portion of sample treatment buffer $(0.75 \mathrm{~g}$ Tris, $5 \mathrm{ml}$ mercaptoethanol, $5 \mathrm{~g}$ sucrose and enough deionized water to bring the volume up to $100 \mathrm{ml}, \mathrm{pH} 6 \cdot 8$ ) was 
added and the solution was mixed. Then $0 \cdot 1 \mathrm{ml} 20 \%$ SDS was added. The mixture was incubated at $95^{\circ} \mathrm{C}$ for $10 \mathrm{~min}$, cooled on ice and centrifuged at $11000 \mathrm{~g}$ for $5 \mathrm{~min}$ in an Eppendorf centrifuge. Supernatants were stored at $-20^{\circ} \mathrm{C}$. SDS-PAGE of whole-cell protein extracts was performed by the procedure of Sambrook et al. (1989) in a Miniprotean II electrophoresis cell (Bio-Rad) by using $12 \%$ separation gels. The gels were stained with Coomassie blue.

Determination of DNA base composition. Cells from a culture of each isolate were harvested, washed and resuspended in $0 \cdot 15 \mathrm{M} \mathrm{NaCl} / 0.01 \mathrm{M}$ sodium EDTA buffer ( $\mathrm{pH} 8 \cdot 0$ ). The cells were lysed at $60{ }^{\circ} \mathrm{C}$ for $10 \mathrm{~min}$ by adding SDS to a final concentration of $1 \%(\mathrm{w} / \mathrm{v})$. The DNA was extracted and purified by the method of Marmur (1961). The G+C content was determined from the midpoint $\left(T_{\mathrm{m}}\right)$ of the thermal denaturation profile (Marmur \& Doty, 1962) obtained with a Perkin-Elmer model UV/Vis $551 \mathrm{~S}$ spectrophotometer at $260 \mathrm{~nm}$. $T_{\mathrm{m}}$ was determined by the method of Ferragut \& Leclerc (1976) and the $\mathrm{G}+\mathrm{C}$ content was calculated by using the equation of Owen \& Hill (1979). The $T_{m}$ of reference DNA from Escherichia coli NCTC 9001 in $0 \cdot 1 \times \mathrm{SSC}$ $(1 \times \mathrm{SSC}$ is $0.15 \mathrm{M} \mathrm{NaCl}, 0.015 \mathrm{M}$ sodium citrate $)$ was $74 \cdot 6{ }^{\circ} \mathrm{C}$ (Owen \& Pitcher, 1985).

DNA-DNA hybridization. Levels of DNA-DNA hybridization between bacterial isolates and type strains were determined spectrophotometrically by the initial renaturation method of De Ley et al. (1970).

16S rRNA sequence determination and analysis. Genomic DNA was extracted as described by Pitcher et al. (1989). The 16S rRNA gene was amplified by using the PCR method (Saiki et al., 1988). The forward amplification primer was 27F, 5'-AGAGTTTGATCCTGGCTCAG-3' (corresponding to positions 8-27 in the $16 \mathrm{~S}$ rDNA nucleotide sequence of $E$. coli), and the reverse amplification primer was $1522 \mathrm{R}$, 5'-AAGGAGGTGATCCAGCCGCA-3' (positions 15411522). The PCR products were purified by using the QIAquick PCR purification Kit (Qiagen). Purified PCR products were sequenced with an Applied Biosystems model 377 DNA sequencer, as recommended by the manufacturer (Perkin-Elmer), by using the ABI PRISM Dye Terminator Cycle Sequencing Ready Reaction Kit with AmpliTaq DNA Polymerase. The following primers were used for sequencing: 358F, 5'-CTCCTACGGGAGGCAGCAGT-3' (positions 339-358); 536F, 5'-CAGCAGCCGCGGTAATAC-3' (519-536); 926F， 5'-AACTCAAAGGAATTGACGG-3' (908-926); 1112F, 5'-AGTCCCGCAACGAGCGCAAC-3' (1093-1112); 1241F , 5'-GCTACACACGTGCTACAATG3' (1222-1241); 339R, 5'-ACTGCTGCCTCCCGTAGGAG-3' (358-339); 519R, 5'-GTATTACCGCGGCTGCTG-3' (536-519); and 1093R, 5'-GTTGCGCTCGTTGCGGGACT-3' (1112-1093).

The sequences were assembled by the program Auto Assembler (Applied Biosystems). Phylogenetic analysis was performed using the software package GeneCompar (Applied Maths), after including the consensus sequence in an alignment of small ribosomal subunit sequences collected from the international nucleotide sequence library at EMBL. This alignment was pairwise, calculated using an open gap penalty of $100 \%$ and a unit gap penalty of $0 \%$. A similarity matrix was created by homology calculation with a gap penalty of $0 \%$ after discarding unknown bases. A phylogenetic tree was constructed by applying the neighbourjoining method (Saitou \& Nei, 1987).

\section{RESULTS AND DISCUSSION}

\section{Morphological and growth characteristics}

The Antarctic bacterial isolates were Gram-negative, rod-shaped, non-spore-forming organisms. On TSA agar incubated at $15^{\circ} \mathrm{C}$, young colonies were circular, smooth, convex, slightly mucoid and red-brown, with a diameter of 1-2 mm. Neither diffusible pigments nor bioluminescence were observed. NF12, NF22 ${ }^{\mathrm{T}}$ and NF24 grew well at $15^{\circ} \mathrm{C}$ in standard bacteriological nutrient media such as TSB or TSA. Cells were motile by means of a single unsheathed polar flagellum (Fig. 1). After $24 \mathrm{~h}$ incubation in liquid medium, larger cells appeared in the population and, sometimes, filamentous forms (Fig. 2) about $10 \mu \mathrm{m}$ long were observed. None of the isolates required $\mathrm{Na}^{+}$to grow. The $\mathrm{pH}$ range for growth was 6-9.5 and the growth temperature range was $4-30{ }^{\circ} \mathrm{C}$ for NF12 and $4-20{ }^{\circ} \mathrm{C}$ for NF22 ${ }^{\mathrm{T}}$ and NF24.

\section{Phenotypic characterization}

The physiological and biochemical properties of the Antarctic isolates are summarized in Table 2. The strains were chemo-organotrophic and capable of respiratory and fermentative metabolism. All of the strains were positive for cytochrome oxidase and catalase. They reduced nitrate to nitrite and nitrogen gas was not formed from nitrite. NF12, NF22 ${ }^{\mathrm{T}}$ and NF24 were able to grow anaerobically by reducing TMAO and ferric compounds while using DL-lactate as electron donor. $\mathrm{NF} 22^{\mathrm{T}}$ was the only strain capable

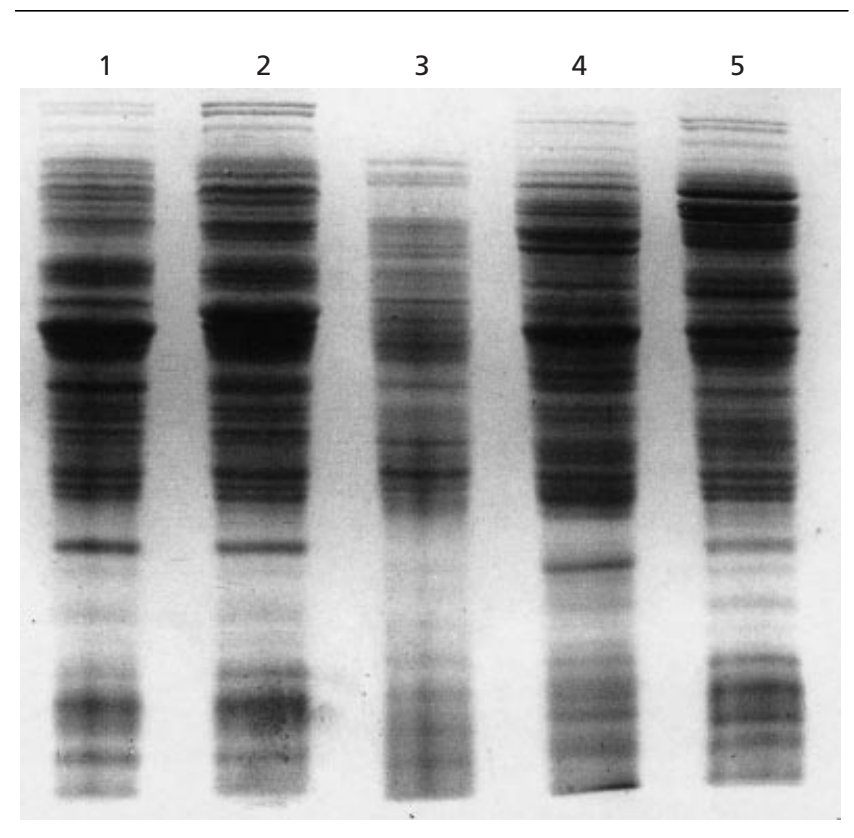

Fig. 3. SDS-PAGE gel of whole-cell proteins. Lanes: $1, \mathrm{NF} 24 ; 2$, $\mathrm{NF} 12 ; 3$, NF22 $; 4$, Shewanella baltica CECT $323^{\top}$; 5 , Shewanella algae CECT 331. 
Table 3. Fatty acid composition of bacterial isolates NF12, NF22 ${ }^{\top}$, NF24 and Shewanella algae CECT 331*

$n$, Number of strains examined; TR, trace $(<1 \%)$; summed feature 1 , fatty acids $14: 1 \omega 5 c$ and $14: 1 \omega 5 t$ could not be separated by GC by using the MIS software package and were considered together as summed feature 1; summed feature 2 consists of 13:0 $3 \mathrm{OH}, 15: 1$ iso $\mathrm{H}$ and 15:1 iso; summed feature 3 consists of unknown 10.928 (fatty acid whose identity is unknown and whose equivalent chain-length is 10.928), $14: 03 \mathrm{OH}$ and 16:1 iso I; summed feature 7 consists of 18:1 $\omega 7 c, 18: 1 \omega 9 t$ and 18:1 $\omega 12 t$ (not separated by MIS); summed feature 8 consists of 19:1 and unknown 18.756; summed feature 9 consists of unknown 18.846 and 18.858. In addition, small amounts (less than $3 \%$ of the total fatty acids) of one or more of the following fatty acids were found in the strains studied: 9:0, 10:0, 10:0 iso, 11:0, 10:0 3OH, unknown 11.798, 12:0 iso, 11:0 iso 3OH, unknown 12.487, 13:1 AT $12-13,12: 0$ iso $3 \mathrm{OH}, 12: 13 \mathrm{OH}, 15: 1$ iso, $15: 0$ anteiso, $14: 0$ iso $3 \mathrm{OH}, 16: 0$ iso, $16: 1 \omega 5 c$, iso $17: 1 \omega 9 c, 15: 03 \mathrm{OH}, 17: 0$ anteiso, 18:0 iso, 18:1 $\omega 5 c, 19: 0$ iso, 19:0 10Me and 20:0 iso.

\begin{tabular}{|c|c|c|c|c|c|c|c|}
\hline \multirow[t]{3}{*}{ Fatty acid } & \multicolumn{7}{|c|}{ Percentage of total fatty acid at: } \\
\hline & \multicolumn{3}{|c|}{$15^{\circ} \mathrm{C}$} & \multirow{2}{*}{$\begin{array}{c}\text { Room } \\
\text { temperature } \\
\text { Shewanella } \\
\text { algae }(n=6)\end{array}$} & \multicolumn{3}{|c|}{$\mathbf{8}^{\circ} \mathrm{C}$} \\
\hline & $\mathrm{NF12}(n=5)$ & $\mathrm{NF}^{\mathrm{T}}(n=4)$ & $\mathrm{NF24}(n=6)$ & & $\mathrm{NF12}(n=2)$ & $\mathrm{NF}^{\mathrm{T}}(n=2)$ & $\mathrm{NF24}(n=1)$ \\
\hline $12: 0$ & $3 \cdot 5-7 \cdot 7$ & $3 \cdot 5-5$ & $3-4 \cdot 4$ & $1 \cdot 5-1.9$ & $4 \cdot 8$ & 4 & $3 \cdot 16$ \\
\hline $11: 03 \mathrm{OH}$ & $\mathrm{TR}^{\mathrm{c}}$ & TR & TR & $\mathrm{TR}-1 \cdot 7$ & TR & TR & TR \\
\hline $13: 0$ iso & $7 \cdot 5-16 \cdot 7$ & $8 \cdot 9-10 \cdot 1$ & $8 \cdot 8-17$ & $4 \cdot 8-9$ & $7 \cdot 8-8 \cdot 4$ & $6 \cdot 8-7 \cdot 1$ & $8 \cdot 7$ \\
\hline $13: 0$ & $\mathrm{TR}-4$ & $1-1 \cdot 8$ & $\mathrm{TR}-2 \cdot 4$ & $\mathrm{TR}-2$ & $1 \cdot 7-2 \cdot 6$ & $1 \cdot 6-2$ & $\mathrm{TR}$ \\
\hline $12: 03 \mathrm{OH}$ & $1 \cdot 4-4 \cdot 7$ & $2 \cdot 4-2 \cdot 6$ & $1 \cdot 5-2 \cdot 4$ & $2 \cdot 1-2 \cdot 7$ & $2-2 \cdot 6$ & $2 \cdot 2$ & $2 \cdot 1$ \\
\hline $14: 0$ iso & $\mathrm{TR}-1 \cdot 8$ & TR & $\mathrm{TR}-2$ & TR & TR & 1 & TR \\
\hline $14: 0$ & $2 \cdot 3-4 \cdot 6$ & $2 \cdot 4-3 \cdot 6$ & $3 \cdot 8-4 \cdot 9$ & TR & $3 \cdot 3$ & $2 \cdot 7$ & $3 \cdot 7$ \\
\hline $13: 0$ iso $3 \mathrm{OH}$ & $4 \cdot 5-12$ & $3 \cdot 6-4 \cdot 2$ & $5 \cdot 2-7$ & $4 \cdot 9-6 \cdot 7$ & $4 \cdot 8-6 \cdot 1$ & $3 \cdot 4$ & $5 \cdot 7$ \\
\hline $15: 0$ iso & $6 \cdot 7-9 \cdot 1$ & $7 \cdot 6-10 \cdot 3$ & $8 \cdot 4-10 \cdot 7$ & $17 \cdot 3-28 \cdot 8$ & $5 \cdot 6-6 \cdot 6$ & $5 \cdot 9-6 \cdot 7$ & $10 \cdot 6$ \\
\hline $15: 1 \omega 8 c$ & $\mathrm{TR}-2 \cdot 6$ & $\mathrm{TR}-1 \cdot 1$ & $\mathrm{TR}-1 \cdot 4$ & TR & $1 \cdot 5-2 \cdot 1$ & $1 \cdot 3-1 \cdot 7$ & $\mathrm{TR}$ \\
\hline $15: 1 \omega 6 c$ & $\mathrm{TR}-2 \cdot 5$ & $\mathrm{TR}$ & $\mathrm{TR}-1 \cdot 4$ & $\mathrm{TR}$ & $1 \cdot 6-2$ & $1 \cdot 7$ & 1 \\
\hline $15: 0$ & $2 \cdot 2-8 \cdot 8$ & $5 \cdot 3-5 \cdot 7$ & $2 \cdot 4-7$ & $2 \cdot 2-3 \cdot 5$ & $4 \cdot 9-7 \cdot 2$ & $5 \cdot 8-7 \cdot 1$ & $2 \cdot 6$ \\
\hline $16: 1 \omega 9 c$ & $1 \cdot 1-1 \cdot 9$ & TR & $1 \cdot 1-1 \cdot 4$ & TR & $1 \cdot 2$ & TR & 1 \\
\hline $16: 1 \omega 7 c$ & $24 \cdot 9-35 \cdot 1$ & $23 \cdot 7-24 \cdot 8$ & $23 \cdot 9-36 \cdot 6$ & $6 \cdot 7-12 \cdot 8$ & $32 \cdot 3$ & $27 \cdot 2-28 \cdot 4$ & $36 \cdot 6$ \\
\hline $16: 0$ & 4-9·1 & $9 \cdot 7-11 \cdot 4$ & $5 \cdot 4-13 \cdot 4$ & $3 \cdot 7-6 \cdot 3$ & $6 \cdot 4$ & $6 \cdot 7-6 \cdot 9$ & $7 \cdot 1$ \\
\hline $15: 0$ iso $3 \mathrm{OH}$ & TR & TR & TR & $\mathrm{TR}-1 \cdot 2$ & TR & TR & TR \\
\hline $17: 0$ iso & $\mathrm{TR}$ & $\mathrm{TR}$ & $\mathrm{TR}$ & $2 \cdot 5-4 \cdot 4$ & $\mathrm{TR}$ & $\mathrm{TR}$ & $\mathrm{TR}$ \\
\hline $17: 1 \omega 8 c$ & $2 \cdot 6-6 \cdot 4$ & $6 \cdot 9-8 \cdot 4$ & $2 \cdot 8-6 \cdot 4$ & $14 \cdot 7-20 \cdot 5$ & $6 \cdot 9-7 \cdot 5$ & $10 \cdot 7-11 \cdot 5$ & $4 \cdot 7$ \\
\hline $17: 1 \omega 6 c$ & $\mathrm{TR}-1 \cdot 2$ & $1-1 \cdot 3$ & TR & $\mathrm{TR}-1$ & $1 \cdot 2$ & $2-2 \cdot 2$ & 1 \\
\hline $17: 0$ & $\mathrm{TR}$ & $1 \cdot 8-2 \cdot 3$ & $\mathrm{TR}$ & $3 \cdot 5-4 \cdot 4$ & $\mathrm{TR}$ & $1 \cdot 7$ & $\mathrm{TR}$ \\
\hline $18: 1 \omega 9 c$ & $\mathrm{TR}-2$ & $1 \cdot 2-1 \cdot 6$ & $\mathrm{TR}-1 \cdot 8$ & $2 \cdot 3-4 \cdot 6$ & TR & $\mathrm{TR}-1$ & $1 \cdot 5$ \\
\hline $18: 0$ & $\mathrm{TR}-2 \cdot 1$ & $\mathrm{TR}$ & $\mathrm{TR}-1 \cdot 1$ & $\mathrm{TR}$ & $\mathrm{TR}$ & $\mathrm{TR}$ & $\mathrm{TR}$ \\
\hline Summed feature 1 & TR & $0-\mathrm{TR}$ & TR & - & - & - & TR \\
\hline Summed feature 2 & $\mathrm{TR}-1 \cdot 3$ & $1 \cdot 3-1 \cdot 4$ & $\mathrm{TR}-1$ & $2 \cdot 2-3 \cdot 9$ & $1 \cdot 1$ & $1 \cdot 4$ & TR \\
\hline Summed feature 3 & $\mathrm{TR}-2 \cdot 4$ & $1 \cdot 3-1 \cdot 5$ & $\mathrm{TR}-1$ & $1-1 \cdot 2$ & TR & $\mathrm{TR}$ & $\mathrm{TR}$ \\
\hline Summed feature 7 & $\mathrm{TR}-4 \cdot 7$ & $3 \cdot 7-4 \cdot 7$ & $\mathrm{TR}-4 \cdot 1$ & $3 \cdot 7-6$ & $2 \cdot 5-3 \cdot 6$ & $4-4 \cdot 8$ & - \\
\hline Summed feature 8 & - & - & - & TR & - & - & - \\
\hline Summed feature 9 & TR & $0-\mathrm{TR}$ & TR & - & - & - & - \\
\hline
\end{tabular}

of producing hydrogen sulfide from thiosulfate. Fermentation of carbohydrates by bacterial isolates was accompanied by acid production, but no gas was observed. The strains did not show haemolytic activity.

On the basis of the phenotypic characterization, it was found that the isolates belong to the genus Shewanella (Venkateswaran et al., 1999). According to the phenotypic differentiation of Shewanella species reported by Venkateswaran et al. (1999), these bacterial isolates were phenotypically similar to Shewanella frigidi- marina (Bowman et al., 1997). NF12, $\mathrm{NF} 22^{\mathrm{T}}$ and NF24 could grow anaerobically by dissimilatory iron reduction, or by carbohydrate fermentation. The three isolates could ferment D-glucose and could grow at $20{ }^{\circ} \mathrm{C}$. They were psychrophilic and halotolerant strains. Gelatinase was produced by $\mathrm{NF} 12$ and NF22 ${ }^{\mathrm{T}}$. Venkateswaran et al. (1999), in their recent study on the polyphasic taxonomy of the genus Shewanella, point out that the inability to ferment glucose has traditionally been characteristic of shewanellae. However, Bowman et al. (1997) have reported glucose 
Table 4. Isoprenoid quinone composition of the bacterial isolates and Shewanella strains

TR, Trace amounts $(<1 \%)$; Q-6, Q-7, Q-8 and Q-9, ubiquinones with six, seven, eight and nine isoprene units, respectively; MK-7 and MK-8, menaquinones with seven and eight isoprene units, respectively; MMK-7, methylmenaquinone with seven isoprene units.

\begin{tabular}{|lccccccc|}
\hline \multirow{2}{*}{ Strain } & \multicolumn{9}{c|}{ Quinone composition (\%) of: } \\
\cline { 2 - 8 } & Q-6 & Q-7 & Q-8 & Q-9 & MK-7 & MK-8 & MMK-7 \\
\hline Shewanella algae CECT 331 & TR & $9 \cdot 4$ & $36 \cdot 6$ & TR & $47 \cdot 8$ & $1 \cdot 2$ & 4 \\
Shewanella baltica CECT 323 & TR & $63 \cdot 8$ & 11 & - & TR & - & $23 \cdot 3$ \\
NF12 & 1 & $44 \cdot 4$ & 17 & - & $35 \cdot 7$ & TR & 1 \\
NF22 & TR & $7 \cdot 4$ & $3 \cdot 9$ & - & $83 \cdot 7$ & $3 \cdot 2$ \\
NF24 & $1 \cdot 5$ & 18 & $1 \cdot 7$ & - & $76 \cdot 7$ & TR & $1 \cdot 7$ \\
\hline
\end{tabular}

Table 5. Levels of DNA relatedness among strains

\begin{tabular}{|c|c|c|c|c|c|c|}
\hline \multirow[t]{2}{*}{ Strain } & \multicolumn{6}{|c|}{ Percentage DNA binding with: } \\
\hline & $\begin{array}{c}\text { Shewanella } \\
\text { hanedai } \\
\text { CECT 5017 }\end{array}$ & $\begin{array}{l}\text { Shewanella } \\
\text { frigidimarina } \\
\text { LMG } 1947^{\mathrm{T}}\end{array}$ & $\begin{array}{c}\text { Shewanella } \\
\text { algae CECT } \\
331\end{array}$ & NF12 & $\mathrm{NF}^{2}{ }^{\mathrm{T}}$ & NF24 \\
\hline Shewanella putrefaciens $\mathrm{LMG} 2268^{\mathrm{T}}$ & & & & 11 & 7 & 12 \\
\hline Shewanella putrefaciens LMG 2369 & & & & 14 & 15 & \\
\hline Shewanella hanedai CECT 5017 & 100 & & & & & \\
\hline Shewanella frigidimarina $\mathrm{LMG} 19475^{\mathrm{T}}$ & & 100 & & 74 & & 70 \\
\hline Shewanella baltica LMG $2250^{\mathrm{T}}$ & & & & 20 & 11 & \\
\hline Shewanella algae CECT 331 & & & 100 & & & \\
\hline Shewanella algae LMG 2265 & & & & 8 & 14 & \\
\hline NF12 & 10 & & 12 & 100 & & \\
\hline $\mathrm{NF} 22^{\mathrm{T}}$ & 13 & 24 & 6 & 38 & 100 & 32 \\
\hline NF24 & 14 & & 13 & 88 & & 100 \\
\hline
\end{tabular}

fermentation in Shewanella benthica and Shewanella frigidimarina.

\section{SDS-PAGE protein profile patterns}

The total-protein profile patterns of strains NF12 and NF24 were practically identical and similar to the profiles of Shewanella algae CECT 331 and Shewanella baltica CECT $323^{\mathrm{T}}$, respectively (Fig. 3). However, $\mathrm{NF} 22^{\mathrm{T}}$ was not so similar with respect to the protein profiles of the other isolates and Shewanella species.

\section{Cellular fatty acid composition}

The fatty acid composition of the bacterial isolates and Shewanella algae CECT 331 are shown in Table 3. The fatty acid profiles observed in the Antarctic isolates were in accordance with the profiles of other Shewanella species (Moule \& Wilkinson, 1987; Matsui et al., 1991; Nichols et al., 1994; Bowman et al., 1997; Venkateswaran et al., 1998). In the three isolated bacteria the monounsaturated 16:1 $\omega 7 \mathrm{c}$ was the major component. NF12 and NF24 presented high amounts of monounsaturated fatty acids $(16: 1 \omega 7 \mathrm{c}, 17: 1 \omega 8 \mathrm{c})$, followed by terminally branched saturates $(13: 0$ iso, $13: 0$ iso $3 \mathrm{OH}, 15: 0$ iso) and straight-chain saturates (16:0, 15:0, 12:0) as occur in Shewanella algae, Shewanella amazonensis, Shewanella gelidimarina and Shewanella oneidensis. However, NF22 ${ }^{\mathrm{T}}$ had high amounts of monounsaturates, followed by straightchain saturates and terminally branched saturates as found in Shewanella frigidimarina, Shewanella benthica, Shewanella hanedai and Shewanella putrefaciens (Venkateswaran et al., 1999).

\section{Isoprenoid quinone composition}

The quinone compositions are shown in Table 4. $\mathrm{NF} 12, \mathrm{NF}_{2} 2^{\mathrm{T}}$ and NF24 presented ubiquinones, menaquinones and small amounts of methylmenaquinones. Akagawa-Matsushita et al. (1992) pointed out that the presence of both ubiquinones and menaquinones could be a relevant differential characteristic among Shewanella species and other aerobic, motile 


\section{Percentage dissimilarity}
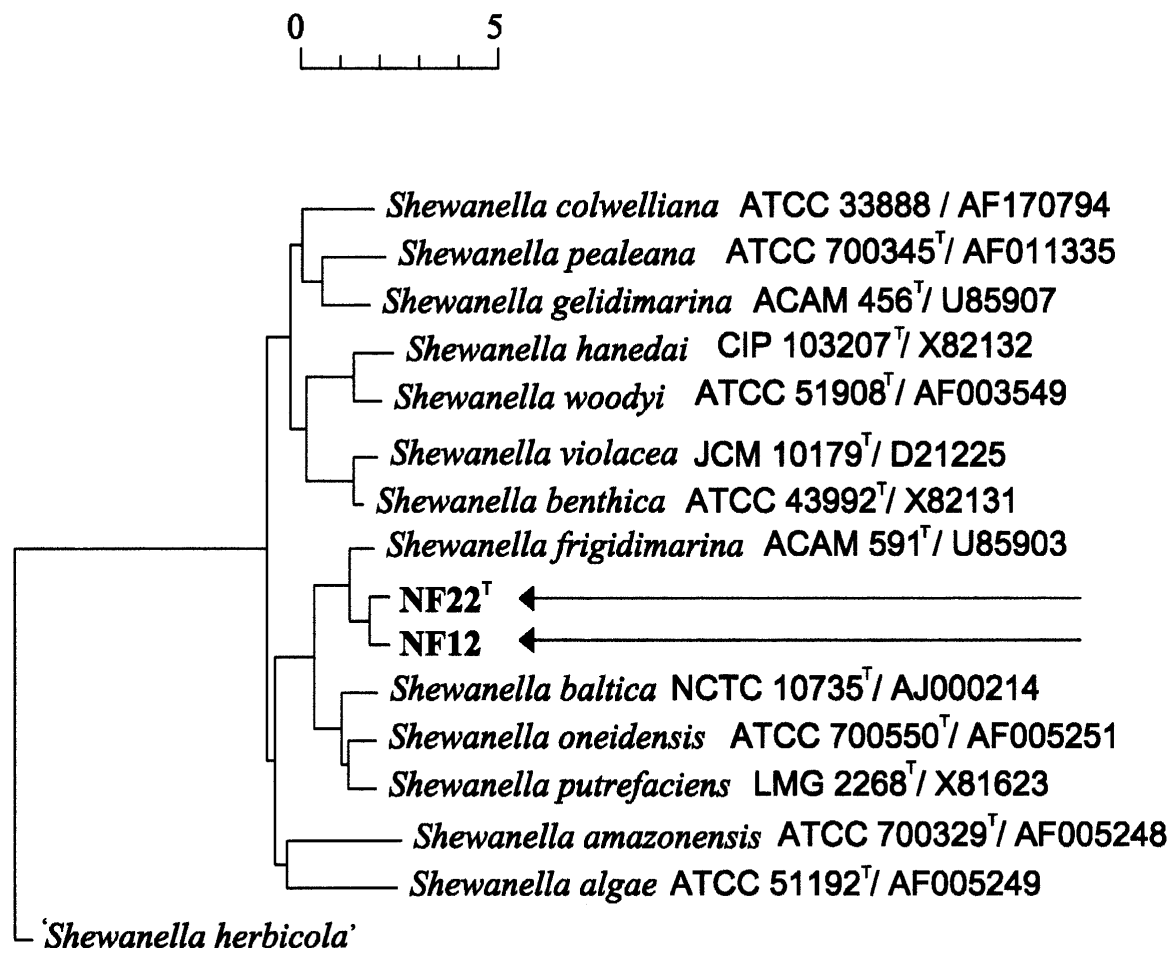

Fig. 4. Phylogenetic tree obtained by neighbour-joining analysis of $16 \mathrm{~S}$ rRNA sequences showing the positions of the Antarctic isolates NF12 and NF22 ${ }^{\top}$, and related organisms. Strain and accession numbers are indicated.

marine bacteria such as Alteromonas, Pseudoalteromonas and Marinomonas. The presence of methylmenaquinones in some strains of Shewanella putrefaciens has been reported by Collins \& Jones (1981), Itoh et al. (1985), Moule \& Wilkinson (1987), Akagawa-Matsushita et al. (1992) and Venkateswaran et al. (1999) (Shewanella oneidensis).

\section{DNA base composition and DNA-DNA hybridization}

The DNA G + C content of the Antarctic isolates was 41-42 $\mathrm{mol} \%$ (Table 2), which agrees with the range described for the genus Shewanella (39-55 mol\%; Venkateswaran et al., 1999). Table 5 shows the levels of DNA-DNA relatedness among the strains studied. NF12 and NF24 presented a DNA reassociation percentage of $88 \%$. The percentage similarity between these bacterial isolates and Shewanella frigidimarina LMG $19475^{\mathrm{T}}$ was over $70 \%$, which places the strains within the same species (Wayne et al., 1987; Stackebrandt \& Goebel, 1994). DNA-DNA similarity between $\mathrm{NF} 12$ and $\mathrm{NF} 22^{\mathrm{T}}$ was $38 \% . \mathrm{NF}^{2} 2^{\mathrm{T}}$ and Shewanella frigidimarina $\mathrm{LMG} 19475^{\mathrm{T}}$ showed a low level of DNA homology $(24 \%)$. The genetic similarity of NF12, NF22 ${ }^{\mathrm{T}}$ and NF24 with the other type strains studied ranged from 6 to $20 \%$.

\section{S rRNA phylogenetic analysis}

16S rRNA phylogenetic studies showed similarities with the type strain of Shewanella frigidimarina, ACAM $591^{\mathrm{T}}$, of $98.7 \%$ to NF12 and $98.9 \%$ to NF22 ${ }^{\mathrm{T}}$. The phylogenetic tree constructed by the neighbourjoining method is shown in Fig. 4. These results suggest that the isolates belong to the genus Shewanella. NF12 and NF24, with a G $+\mathrm{C}$ content of $42 \mathrm{~mol} \%$, belong to the species Shewanella frigidimarina. However, $\mathrm{NF} 22^{\mathrm{T}}$ occupies a separate position in the genus Shewanella. This Antarctic strain is proposed as a new species, designated Shewanella livingstonensis sp. nov.

\section{Description of Shewanella livingstonensis sp. nov.}

Shewanella livingstonensis (li.ving.sto.nen'sis. N.L. masc./fem. adj. livingstonensis pertaining to Livingston Island, Antarctica, where the organism was isolated).

Gram-negative, facultatively anaerobic, rod-shaped cells that are $0.3-0.5 \mu \mathrm{m}$ wide and $1-3 \mu \mathrm{m}$ long when the organism is grown in TSB. Cells occur singly or in pairs and after $24 \mathrm{~h}$ incubation in liquid medium filaments $10 \mu \mathrm{m}$ long are observed. Endospores are not formed. Cells are motile by means of a single polar 
flagellum. Growth occurs at temperatures from 4 to $20^{\circ} \mathrm{C}$. Colonies on TSA are circular, smooth, convex, slightly mucoid and red-brown in colour with a diameter of $1-2 \mathrm{~mm}$ after $5 \mathrm{~d}$ at $15{ }^{\circ} \mathrm{C}$. Growth factors are not required. Sodium ions are not required for growth. Positive in oxidase, catalase, alkaline phosphatase, acid phosphatase, esterase (C4), esterase lipase (C8), leucine arylamidase, cystine arylamidase, naphthol-AS-BI-phosphohydrolase, $\alpha$-glucosidase and $\beta$-galactosidase tests. Positive for hydrolysis of aesculin, Tween, gelatin and casein. Hydrogen sulfide is produced from thiosulfate. Cells are able to reduce nitrate to nitrite and grow anaerobically by reducing TMAO and ferric compounds with lactate as electron donor. Anaerobic growth occurs alternatively by fermentation of D-glucose, maltose, cellobiose, sucrose, D-mannose, D-mannitol, D-galactose, D-xylose, $\mathrm{N}$-acetylglucosamine and trehalose. Growth occurs on D-glucose, maltose, cellobiose, sucrose, D-mannose, Dmannitol, D-galactose, D-xylose, $N$-acetylglucosamine, trehalose, malonate, succinate, D-ribose and DLlactate. The main cellular fatty acids are monounsaturated acids $(16: 1 \omega 7 c, 17: 1 \omega 8 c)$ followed by straight-chain saturates and terminally branched saturates. The $\mathrm{G}+\mathrm{C}$ content of DNA is $41 \mathrm{~mol} \%$. Isolated from water collected from Johnson's Dock (Livingston Island, South Shetland Islands, Antarctica). Strain NF $22^{\mathrm{T}}$ has been deposited in the BCCM/ LMG Bacteria Collection as LMG $19866^{\mathrm{T}}$ and in the Spanish Type Culture Collection as CECT $5933^{\mathrm{T}}$.

\section{ACKNOWLEDGEMENTS}

We would like to thank Josefina Castellví for providing Antarctic samples. We gratefully acknowledge the assistance of F. Garcia (Departament d'Agricultura, Ramaderia i Pesca, Generalitat de Catalunya, Spain) for the fatty acid analysis. We thank the Technical Scientific Services of Barcelona University (Unitat de Microscopia Electrònica, Unitat de Cromatografia, Unitat de Ressonància Magnètica Nuclear) for technical assistance. We acknowledge the BCCM/LMG Identification Service (BCCM/LMG Bacteria Collection, Laboratorium voor Microbiologie, University of Ghent, Ghent, Belgium) for performing the hybridization analysis and $16 \mathrm{~S}$ rRNA sequencing analysis. We also thank Robin Rycroft for revising the manuscript. This work was supported by grant ANT98-1701-E from CICYT (Spain).

\section{REFERENCES}

Aguirre, A. A., Balazas, G. H., Zimmerman, B. \& Spraker, T. R. (1994). Evaluation of hawaiian green turtles (Cheledonia mydas) for potential pathogens associated with fibropapilomas. $J$ Wild Dis 30, 8-15.

Akagawa-Matsushita, M., Itoh, T., Katayama, Y., Kuraishi, H. \& Yamasato, K. (1992). Isoprenoid quinone composition of some marine Alteromonas, Marinomonas, Deleya, Pseudomonas and Shewanella species. J Gen Microbiol 138, 2275-2281.

Bauer, A. N., Kirby, W. M. M., Sherry, J. C. \& Turck, M. (1966). Antibiotic susceptibility testing by a standardized single disc method. Am J Clin Pathol 45, 493-496.
Bowman, J. P., McCammon, S. A., Nichols, D. S., Skerratt, J. H., Rea, S. M., Rea Nichols, P. D. \& McMeekin, T. A. (1997). Shewanella gelidimarina sp. nov. and Shewanella frigidimarina $\mathrm{sp}$. nov., novel antarctic species with the ability to produce eicosapentaenoic acid $(20: 5 \omega 3)$ and grow anaerobically by dissimilatory Fe(III) reduction. Int J Syst Bacteriol 47, 10401047.

Brink, A. J., van Straten, A. \& van Rensburg, A. J. (1995). Shewanella (Pseudomonas) putrefaciens bacteremia. Clin Infect Dis 20, 1327-1332.

Collins, M. D. \& Jones, D. (1981). Distribution of isoprenoid quinone structural types in bacteria and their taxonomic implications. Microbiol Rev 45, 316-354.

Cowan, S. T. \& Steel, K. J. (1993). Manual for the Identification of Medical Bacteria, 3th edn. Edited and revised by G. I. Barrow \& R. K. A. Feltham. Cambridge: Cambridge University Press.

Coyne, V. E., Pillidge, C. J., Sledjeski, D. D., Hori, H., Ortiz-Conde, B. A., Muir, D. G., Weiner, R. M. \& Colwell, R. R. (1989). Reclassification of Alteromonas colwelliana to the genus Shewanella by DNA-DNA hybridization, serology and 5S ribosomal RNA sequence data. Syst Appl Microbiol 12, 275-279.

Debois, J., Degreef, H., Vandepitte, J. \& Spaepen, J. (1975). Pseudomonas putrefaciens as a cause of infection in human. $J$ Clin Pathol 28, 993-996.

De Ley, J., Cattoir, H. \& Reynaerts, A. (1970). The quantitative measurement of DNA hybridization from renaturation rates. Eur J Biochem 12, 133-142.

Derby, H. A. \& Hammer, B. W. (1931). Bacteriology of butter. IV. Bacteriological studies on surface taint butter. Iowa Agric Exp Stn Res Bull 145, 389-416.

DiChristina, T. J. \& DeLong, E. F. (1994). Isolation of anaerobic respiratory mutants of Shewanella putrefaciens and genetic analysis of mutants deficient in anaerobic growth on $\mathrm{Fe}^{3+} . J$ Bacteriol 176, 1468-1474.

Ferragut, C. \& Leclerc, H. (1976). Etude comparative des méthodes de determination du Tm de 1'ADN bactérien. Ann Microbiol (Paris) 127, 223-235.

Itoh, T., Funabashi, H., Katayama-Fujimora, Y., Iwasaki, S. \& Kuraishi, H. (1985). Structure of methylmenaquinone-7 isolated from Alteromonas putrefaciens IAM 12079. Biochim Biophys Acta 840, 51-55.

Jeffries, C. D., Holtman, D. F. \& Guse, D. G. (1957). Rapid method for determining the activity of microorganisms on nucleic acids. $J$ Bacteriol 73, 590.

Jensen, M. J., Tebo, B. M., Baumann, P., Mandel, M. \& Nealson, K. H. (1980). Characterization of Alteromonas hanedai (sp. nov.), a non-fermentative luminous species of marine origin. Curr Microbiol 3, 311-315.

Kovács, N. (1956). Identification of Pseudomonas pyocyanea by the oxidase reaction. Nature 178, 703.

Lee, J. V., Gibson, D. M. \& Shewan, J. M. (1977). A numerical taxonomic study of some pseudomonas-like marine bacteria. $J$ Gen Microbiol 98, 439-451.

Leifson, E. (1963). Determination of carbohydrate metabolism of marine bacteria. J Bacteriol 85, 1183-1184.

Lelliot, R. A., Billing, E. \& Hayward, A. C. (1966). A determinative scheme for the fluorescent plant pathogenic pseudomonads. $J$ Appl Bacteriol 29, 470-489.

Leonardo, M. R., Moser, D. P., Barbieri, E., Brantner, C. A., MacGregor, B. J., Paster, B. J., Stackebrandt, E. \& Nealson, K. H. (1999). Shewanella pealeana sp. nov., a member of the microbial 
community associated with the accessory nidamental gland of the squid Loligo pealei. Int J Syst Bacteriol 49, 1341-1351.

Levin, R. E. (1972). Correlation of DNA base composition and metabolism of Pseudomonas putrefaciens isolates from food, human clinical specimens, and other sources. Antonie Leeuwenhoek 38, 121-127.

Lovely, D. R., Caccavo, F., Jr \& Phillips, E. J. P. (1992). Acetate oxidation by dissimilatory $\mathrm{Fe}(\mathrm{III})$ reducers. Appl Environ Microbiol 58, 3205-3208.

MacDonell, M. T. \& Colwell, R. R. (1985). Phylogeny of the Vibrionaceae, and recommendation for two new genera, Listonella and Shewanella. Syst Appl Microbiol 6, 171-182.

Makemson, J. C., Fulayfil, N. R., Landry, W., Van Ert, L. M., Wimpee, C. F., Widder, E. A. \& Case, J. F. (1997). Shewanella woodyi (sp. nov.), a new exclusively respiratory luminous bacterium isolated from the Alboran Sea. Int $J$ Syst Bacteriol 47, 1034-1039.

Marmur, J. (1961). A procedure for the isolation of deoxyribonucleic acids from microorganisms. J Mol Biol 3, 208-218.

Marmur, J. \& Doty, P. (1962). Determination of the base composition of deoxyribonucleic acid from its thermal denaturation temperature. J Mol Biol 5, 109-118.

Matsui, Y., Suzuki, S., Suzuki, T. \& Takama, K. (1991). Phospholipid and fatty acid compositions of Alteromonas putrefaciens and A. haloplanktis. Lett Appl Microbiol 12, 51-53.

Minnikin, D. E., O’Donnell, A. G., Goodfellow, M., Alderson, G., Athalye, M., Schaal, A. \& Parlett, J. H. (1984). An integrated procedure for the extraction of bacterial isoprenoid quinones and polar lipids. J Microbiol Methods 2, 233-241.

Moule, A. L. \& Wilkinson, S. G. (1987). Polar lipids, fatty acids, and isoprenoid quinones of Alteromonas putrefaciens (Shewanella putrefaciens). Syst Appl Microbiol 9, 192-198.

Myers, C. R. \& Nealson, K. H. (1988). Bacterial manganese reduction and growth with manganese oxide as the sole electron acceptor. Science 240, 1319-1321.

Myers, C. R. \& Nealson, K. H. (1990). Respiration-linked proton translocation coupled to anaerobic reduction of manganese (IV) and iron (III) in Shewanella putrefaciens MR-1. J Bacteriol 172, 6232-6238.

Nealson, K. H., Myers, C. R. \& Wimpee, B. (1991). Isolation and identification of manganese reducing bacteria, and estimates of microbial manganese reducing bacteria, and estimates of microbial manganese reducing potential in the Black Sea. Deep Sea Res 38, S907-S920.

Nichols, D. S., McMeekin, T. A. \& Nichols, P. D. (1994). Manipulation of polyunsaturated, branched-chain and trans-fatty acid production in Shewanella putrefaciens strain ACAM 342. Microbiology 140, 577-584.

Nozue, H., Hayashi, T., Hashimoto, Y., Ezaki, T., Hamasaki, K., Ohwada, K. \& Terawaki, Y. (1992). Isolation and characterization of Shewanella alga from human clinical specimens and emendation of the description of S. alga Simidu et al. 1990, 335. Int J Syst Bacteriol 42, 628-634.

Owen, R. J. \& Hill, L. R. (1979). The estimation of base compositions, base pairing and genome size of bacterial deoxyribonucleic acids. In Identification Methods for Microbiologists, 2nd edn, pp. 217-296. Edited by F. A. Skinner \& D. W. Lovelock. London: Academic Press.

Owen, R. J. \& Pitcher, D. (1985). Current methods for estimating DNA base composition and levels of DNA-DNA hybridization. In Chemical Methods in Bacterial Systematics, pp. 67-93.
Edited by M. Goodfellow \& E. Minnikin. London: Academic Press.

Palleroni, N. J. \& Doudoroff, M. (1972). Some properties and taxonomic subdivisions of the genus Pseudomonas. Annu Rev Phytopathol 10, 73-100.

Parker, L. L. \& Levin, R. E. (1983). Relative incidence of Alteromonas putrefaciens and Pseudomonas putrefaciens in ground beef. Appl Environ Microbiol 45, 769-799.

Pitcher, D. G., Saunders, N. A. \& Owen, R. J. (1989). Rapid extraction of bacterial genomic DNA with guanidium thiocyanate. Lett Appl Microbiol 8, 151-156.

Saffarini, D. A., DiChristina, T. J., Bermudes, D. \& Nealson, K. H. (1994). Anaerobic respiration of Shewanella putrefaciens requires both chromosomal and plasmid-borne genes. FEMS Microbiol Lett 119, 271-278.

Saiki, R. K., Gelfand, D. H., Stoffe, S., Scharf, S. J., Higuchi, R., Horn, G. T., Mullis, K. B. \& Erlich, H. A. (1988). Primer-directed enzymatic amplification of DNA with a thermostable DNA polymerase. Science 239, 487-491.

Saitou, N. \& Nei, M. (1987). The neighbor-joining method: a new method for reconstructing phylogenetic trees $\mathrm{Mol}$ Biol Evol 4, 406-425.

Sambrook, J., Fritsch, E. F. \& Maniatis, T. (1989). Molecular Cloning: a Laboratory Manual, 2nd edn. Cold Spring Harbor, NY : Cold Spring Harbor Laboratory.

Semple, K. M. \& Westlake, D. W. S. (1987). Characterization of iron reducing Alteromonas putrefaciens strains from oil field fluids. Can J Microbiol 33, 366-371.

Shewan, J. M. (1974). The biodeterioration of certain proteinaceous foodstuffs at chill temperatures. In Industrial Aspects of Biochemistry. Edited by B. Spencer. London: North-Holland Publishing Company.

Shewan, J. M. (1977). The bacteriology of fresh and spoiling fish and the biochemical changes induced by bacterial action. In Proceedings of the Conference on Handling, Processing and Marketing of Tropical Fish, pp. 51-66. London: Tropical Products Institute.

Shewan, J. M., Hobbs, G. \& Hodgkiss, W. (1960). A determinative scheme for the identification of certain genera of Gram-negative bacteria with special reference to Pseudomonadaceae. J Appl Bacteriol 23, 379-390.

Sierra, G. (1957). A simple method for the detection of lipolytic activity of microorganisms and some observations on the influence of contact between cells and fatty substrates. Antonie Leeuwenhoek 23, 37-52.

Simidu, U., Kita-Tsukamoto, K., Yasumoto, T. \& Yotsu, M. (1990). Taxonomy of four marine bacterial strains that produce tetrodotoxin. Int J Syst Bacteriol 40, 331-336.

Stackebrandt, E. \& Goebel, B. M. (1994). Taxonomic note: a place for DNA-DNA reassociation and 16S rRNA sequence analysis in the present species definition in bacteriology. Int $J$ Syst Bacteriol 44, 846-849.

Stenstrom, I. M. \& Molin, G. (1990). Classification of the spoilage flora of fish, with special reference to Shewanella putrefaciens. $J$ Appl Bacteriol 68, 601-618.

Tamaoka, J., Katayama-Fujimura, Y. \& Kuraishi, H. (1983). Analysis of bacterial menaquinone mixtures by high performance liquid chromatography. J Appl Bacteriol 54, 31-36.

Thornley, M. (1960). The differentiation of Pseudomonas from other gram-negative bacteria on the basis of arginine metabolism. J Appl Bacteriol 23, 37-52. 
Trüper, H. G. \& de'Clari, L. (1997). Taxonomic note: Necessary correction of specific epithets formed as substantives (nouns) 'in apposition'. Int J Syst Bacteriol 47, 908-909.

Venkateswaran, K., Dollhopf, M. E., Aller, R., Stackebrandt, E. \& Nealson, K. H. (1998). Shewanella amazonensis sp. nov., a novel metal-reducing facultative anaerobe from amazonian shelf muds. Int J Syst Bacteriol 48, 965-972.

Venkateswaran, K., Moser, D. P., Dollhopf, M. E. \& 10 other authors (1999). Polyphasic taxonomy of the genus Shewanella and description of Shewanella oneidensis sp. nov. Int J Syst Bacteriol 49, 705-724.
Wayne, L. G., Brenner, D. J., Colwell, R. R. \& 9 other authors (1987). International Committee on Systematic Bacteriology. Report of the ad hoc committee on reconciliation of approaches to bacterial systematics. Int J Syst Bacteriol 37, 463-464.

Weiner, R. M., Coyne, V. E., Brayton, P., West, P. A. \& Raiken, S. F. (1988). Alteromonas colwelliana sp. nov., an isolate from oyster habitats. Int J Syst Bacteriol 38, 240-244.

Ziemke, F., Hofle, M. G., Lalucat, J. \& Roselló-Mora, R. (1998). Reclassification of Shewanella putrefaciens Owen's genomic group II as Shewanella baltica sp. nov. Int J Syst Bacteriol 48, 179-186. 